\title{
My Cousin the Physicist
}

\section{Bernardo A. Huberman ${ }^{1}$}

Department of Applied Physics,

Stanford University, USA

E-mail: bahuberman@yahoo.com

It is hard to write about Hector as a member of my family and not convey the context from which we both come from. He grew up in Buenos Aires in the fold of a well to do, large and cultured family that put a strong emphasis on education, an appreciation of the arts and a keen interest in the affairs of the world. His parents travelled frequently to Europe and the US, expected both of their boys (but not their daughter) to have successful careers, and amassed a considerable art collection. Hector's father was a warm and intense man, a physician by profession, with sharp opinions about almost everything (something his son no doubt inherited) and his mother - my father's sister was a kind but emotionally aloof person, with effects on Hector that became evident to me later on in life. She presided over lively social gatherings that took place at their home and which I attended since I was a child. I remember those parties as lively affairs with intense discussions of wide ranging topics to which everyone, and especially Hector, contributed their own sharp opinions.

My father, having become an uncle of Hector and his brother Osvaldo while still an adolescent, had a close and special relation with them that lasted through their lifetimes. As a result Hector used to spend a lot of time at my parents' home and I grew up watching him display his quick wit and critical outlook on almost any aspect of life that came to interest him. His visits were eagerly awaited by all of us, for he loved to entertain us with his stories and enjoyed the attention that he received.

My own decision to become a physicist had a lot to do with the fact that Hector was one already then doing his work at Columbia University. In the few conversations we had during his short visits to Argentina he conveyed to me a sense of the intellectual power and beauty of the discipline, and while telling me that he was skeptical of the likelihood that I could make it as a physicist, he did suggest the steps that I needed to take in order to pursue my graduate work in the US.

Quarks, Strings and the Cosmos - Héctor Rubinstein Memorial Symposium, AlbaNova, Stockholm, Sweden August 9-11, 2010

\footnotetext{
${ }^{1}$ Speaker
} 
It was later on, during my first year in the US, that we finally had a chance to relate on a fairly regular basis given that Hector and his family were then spending a sabbatical at NYU. The conversations we started continued for the rest of his life, both through email and in many places over the world given Hector's predilection for travel far and wide.

I remember him as bright, intellectually tough, and pugnacious, with a curious interest in the income of others while not having much interest in his own. He would talk in pessimistic ways about the mediocrity of some effort or institution and in short notice switch to an enthusiastic description of the latest developments in his field. He would often talk about his wife Helen and children Marco, Aram and Hannah, and also ask about members of the Argentine family that were by then spread throughout the world and who seemed to matter a lot to him. And while critical of almost all events going in the world and ready to announce the imminent decay of countries and enterprises, he also had a warm and endearing way of saying it that made me listen to him with a sympathetic and skeptical smile. It took me a while to realize that his pessimism was rooted in a certain sadness that colored his world outlook, a sadness that I saw not only in the way he thought about life, but was also evident in photos of him taken at happy events, where he exhibits a shy smile rather than the vital laughter of a happy man thoroughly enjoying himself.

Things changed after he collapsed while travelling through Rio de Janeiro's airport. As he said to me, he saw the "other side", which he characteristically described to me as "it is hot in hell". After that he took to look at his life (and heart) with a certain detachment that I found impressive. At the same time he remained fully engaged in whatever he was involved until the end. He kept talking about "the total decay of physics" with the same intensity as before, and continued to describe the joy he found in his five grandchildren whenever we talked. At the same time he talked about the problems with his heart the way one would describe a faulty machine and with no emotional content. When a couple of years ago in Stockholm I asked him about his health he replied with a smile "if one of these I wake up and I'm not in pain, I will know that I'm dead". And he would go on in the same breadth to ask about my family or start describing his latest forays into the magnetism of the early universe. He knew that he did not have much time left and decided to live his life the way he liked it. He travelled, he stayed up to date with his work, he announced the demise of great countries and of science, doubted whether or not he would finish writing a book about the history of particle physics and would make plans to meet in California or Stockholm. Sometimes he would end his emails with a "see you soon, evolution willing".

I saw him last a few months before he died, on the occasion of my visit to Sweden to give a seminar at the University of Stockholm. He did not come to my talk but did attend the dinner Erik Aurell organized after my talk. I sat next to him and took 
advantage of the lively table conversation to switch to Spanish and ask him about his illness. He told me that he was getting increasingly tired and found it hard at times to go through the day. When I asked if he had any regrets he replied "the only regret I have is that where I'm going they don't take cash". I laughed while trying to contain my tears, and he dismissed my reaction by joining the conversation with the rest of the people at dinner. A few minutes later he decided to leave and I walked him to the door of the restaurant. We hugged for a longer time than usual and as he turned towards the exit he said to me, "if you get an email from Hector@hell.com, you’ll know that I died". It was our last encounter.

He was a character. And I loved him and I miss him. 